\title{
The Post-Revolutionary Contestation and Nationalization of American Citizenship
}

On July 17th, 1799, the poet, editor, and publicist, Robert Treat Paine Jr. delivered an oration at a meeting of the Committee of the Young Men of Boston. ${ }^{1}$ In this oration, Treat Paine commemorated the annulment of the 1778 Treaty of Alliance with France. The Franco-American defensive alliance against British military aggression forged in the midst of the American Revolutionary War had lasted for exactly twenty years. Its dissolution, approved by Congress on July 7, 1798, as France and the United States were locked in an undeclared naval war, was not simply the end of a military pact, Treat Paine made clear, but symbolized a deep political and intellectual rift between the 'sister republics'. 'The struggle between Liberty and Despotism, Government and Anarchy, Religion and Atheism, has been gloriously decided', Treat Paine commenced his oration. 'It has proved the victory of principle, the triumph of virtue. France has been foiled, and America is free.' ${ }^{2}$

Treat Paine did not deny that France was once 'considered an amiable nation.' ${ }^{3}$ For his graduation ceremony at Harvard in 1792, he had written a poem tellingly entitled The Nature and Progress of Liberty in which he, like so many Americans had done at the time, expressed his admiration for the revolution in France. 'May struggling France her ancient freedom gain, May Europe's sword oppose her rights in vain', some of the more expressive lines of the poem read. Following a couplet in which the young graduate wished Edmund Burke's fame to rest in 'dark oblivion', the poem went on to record the intimate

1 Robert Treat Paine Jr. (1773-1811), son of the Massachusetts lawyer and politician Robert Treat Paine (1731-1814), one of the signers of the Declaration of Independence, was born Thomas Paine. Partly to make sure he would not be confused with the famous Anglo-American revolutionary pamphleteer Thomas Paine (1736-1809), Thomas Treat Paine changed his first name into Robert, the name of his deceased brother, in 1801. To avoid any confusion, I will refer to him as Robert Treat Paine Jr. or Treat Paine.

2 Thomas Paine [Robert Treat Paine Jr.], An Oration, written at the Request of the Young Men of Boston, and delivered, July 17th, 1799: In Commemoration of the Dissolution of the Treaties, and Consular Convention, between France and the United States of America (Boston, MA: J. Russell, 1799), p. 5 (italics in original). A second edition of the oration was issued in the same year.

3 Treat Paine, An Oration, p. 11 (italics in original). 
bond between 'Columbia's freedom' and the transatlantic language of the 'rights of man', the 'noblest epoch on the historick page!'

However, Treat Paine's solidarity with the French Republic soon deteriorated. In the middle of the 179os, he became the editor of the Boston Federal Orrery, a staunchly Federalist newspaper that was at the frontline of the attacks directed at the democratic-republican societies (viewed by Treat Paine as American incarnations of the French Jacobin clubs). 'Who has forgotten that dubious aera in our history', he asked his public in his 1799 oration, 'when illuminated fraternities were scattered', when 'anarchy and disorganization were the order of the day', and when 'our "civick feasts" were introduced to celebrate French victories?'5 Next to his editorial work, Treat Paine contributed to the forging of an anti-French American national discourse through his 1798 song, Adams and Liberty, perhaps the most popular American patriotic song of the late 1790s. The contrast between the French and American republics was a recurrent theme in the song's lyrics: 'While France her huge limbs bathes recumbent in blood, And Society's base threats with wide dissolution; May Peace like the dove, who returned from the flood, Find an ark of abode in our mild constitution: ${ }^{6}$ Many of those present in the audience on July 17 , 1799, were most likely familiar with the song, or perhaps had once sung along with it.

Treat Paine's published oration for the Committee of the Young Men of Boston, printed in several newspapers, and highly praised by both ex-president George Washington and president John Adams, who considered it 'an effort of a pregnant and prolific genius [...] excited by the purest motives, and governed by the best principles', was thus the endpoint of his ongoing reflection on France's revolutionary republic. Considering that 'the modern Frenchman is educated in a system of moral and religious chimeras', Treat Paine declared at the closing of the tumultuous decade that the 'exulting Ocean [that] now rolls between our shores' is 'an eternal monument of our separation'?

One of the contentions of this chapter is that this story about Robert Treat Paine Jr's intellectual Werdegang is exemplary of a larger transformation in how

4 'The Nature and Progress of Liberty', in: The Works in Verse and Prose of the late Robert Treat Paine, Jun. Esq. with notes. To which are prefixed Sketches of his Life, Character and Writings (Boston, MA: J. Belcher, 1812), pp. 70-77, at p. 75 .

5 Treat Paine, An Oration, p. 20 (italics in original).

6 T. Paine [Robert Treat Paine Jr.], Adams and liberty. A New Patriotic Song (Baltimore, MD: Hanna and Greene, Thomas, Andrews \& Butler, and Solomon Cotton \& Co, 1798). Adams and Liberty had the same tune as the future national anthem The Star-Spangled Banner (originally the tune of To Anacreon in Heaven). See C. Warren and N. Ames, Jacobin and Junto; Or, Early American Politics as viewed in the Diary of Dr. Nathaniel Ames, 1758-1822 (Cambridge, MA: Harvard University Press, 1931), p. 76.

7 Treat Paine, An Oration, p. 11. 
broad segments of American citizens came to evaluate the radicalization of the French Revolution and the Terror. Moreover, this chapter explores what the implications were for the ways in which Americans came to conceptualize citizenship. Building on the work of historian Seth Cotlar and others, I argue that by the late 1790 s and early 1800 , both Federalists and Republicans conceived the notion of American citizenship in decidedly anti-Jacobin, and eventually antiFrench and 'anti-transatlantic' terms. Like Treat Paine, until 1792 most American citizens had praised the French Revolution and the ideals they associated with it. As this chapter demonstrates, from 1793 onwards, within the context of an emerging Republican-Federal partisanship, interpretations of the radicalization and violence of the French Revolution began to diverge. It then goes on to examine how the rise of democratic-republican societies shifted the focus of Federalist reflection, in publications such as Treat Paine's Federal Orrery, to the Jacobin clubs, and moreover, to the ways in which the Jacobin Terror threw an ominous light on the model of democratic citizenship as propounded by these societies. The final section argues that after 1795 reflection on the Jacobin Terror took on new dimensions, as conservative clergymen, motivated partly by anxieties about the religious state of the American people, began to portray the Jacobin Terror as the outcome of a dangerous atheistic philosophy. A wave of antiJacobin conspiracy theories contributed to the blackening of the American 'illuminated fraternaties', as Treat Paine called them. The Terror was accordingly reinterpreted as the empirical substance within a broader counter (French) enlightenment critique that came to serve as one of the foundations of a distinct conception of American citizenship based on order, Christian virtue, and the constitution (excluding slaves, free blacks, women, and native Indians). In the context of the undeclared naval war of 1798-180o, better known as the 'QuasiWar' between the French and American republics, which provided the occasion for Treat Paine's oration, the chapter shows how both Republican and Federalist publicists forged a nationalized conception of American citizenship, and shattered the horizon of a shared transatlantic ideal.

In the early American Republic, the first stages of the French Revolution met with nearly universal approval across the entire political spectrum. ${ }^{8}$ However,

8 L.S. Kramer, 'The French Revolution and the Creation of American Political Culture', in: Klaits and Haltzel (eds.) The Global Ramifications of the French Revolution, pp. 26-54; Wood, Empire of Liberty, pp. 174-175; S.M. Elkins and E.L. McKitrick, The Age of Federalism (New York, N.Y.: Oxford University Press, 1993), pp. 309-310. 
whereas initially the American public generally interpreted the French Revolution as a confirmation of their own revolution, the radicalization in 1792, and the Jacobin Terror in particular, generated highly politicized and conflicting interpretations. The contested interpretations took place within the context of an emerging of political partisanship between Republicans and Federalists. ${ }^{9}$ Neither Republicans nor Federalists identified themselves as being a 'party' in the sense that they believed that there was a multiparty system in which several parties legitimately competed for power. ${ }^{10}$ Essentially, both Republicans and Federalists saw themselves as representing and expressing the only legitimate vision on the American polity and its future, and the other as a threat to the accomplishments of the revolution. News of the violent and intense political conflicts in revolutionary France put this incongruence in the American Republic between the professed classical ideals of unity and the reality of increasing political division in a gloomy perspective.

In addition, a profound sense of the instability of the American republican experiment characterized the 179os. Unlike earlier generations, historians nowadays recognize that the 1790 s were a period beset with conflict, uncertainty, and fear about the fate of the infant American republic..1 The international crises and revolutionary wars in Europe demonstrated to Americans that they could not take their survival as an independent state for granted. The new American constitution had replaced the Articles of Confederation as of March 4, 1789, establishing a national government with a Congress (Senate and House of Representatives), an executive office of President, and a Supreme Court. But it left unanswered central questions about how, in practice, the relationship between national representatives and their constituents would take shape, how and through what channels the 'will of the people' was to be determined, and what role citizens should play in the public sphere. The nature and limits - of the political substance of citizenship were anything but settled. ${ }^{12}$

$9 \quad$ See Chapter three.

10 Even Madison, acknowledging the existence of two 'parties' in 1791, did not approve of the existence of two parties, but saw one party - the Federalist - as 'evil'. Elkins and McKitrick, The Age of Federalism, pp. 266-268.

11 Sharp, American Politics in the Early Republic; Wood, Empire of Liberty. For an older historiography which stresses the passionate and discordant nature of the 1790, see J.R. Howe Jr., 'Republican Thought and the Political Violence of the 179os', American Quarterly 19 (1967), pp. 147-165; M. Smelser, 'The Jacobin Phrenzy: The Menace of Monarchy, Plutocracy, and Anglophilia, 1789-1798', The Review of Politics 21 (1959), pp. 239-258; M. Smelser, 'The Federalist Period as an Age of Passion', American Quarterly 10 (1958), pp. 391-419.

12 Cf. Bradburn, The Citizenship Revolution, p. 3: 'The significance of the ratification of the Constitution is highly overestimated with regard to the definition of citizenship and its institutional settlement. Instead the conflicts of the 1790 s created the political settlement 
Precisely because the American republic was entering uncharted waters, the vicissitudes of the new French Republic became such important points of reference.

If the French Revolution enabled Americans to take stock of their own situation, they did so at a moment in time when the very limits of the American public sphere were explored and tested. The 1790 saw an unparalleled increase, often inspired by and organized around key moments of the French Revolution, of public festivities, parades, and celebrations, an expanding (transatlantic) book and pamphlet market, the emergence and manifestation of popular democratic societies in 1793-1795, and above all, the expansion of a democratic press that was able to reach and connect to a broader reading public than ever before. These public festivities, popular societies, and democratic newspapers drew heavily on the universalistic and egalitarian language of the French Revolution and involved the participation and representation of social groups that were largely excluded from the political system but were now increasingly claiming their place, or given a voice, in the public sphere. The responses to, and interpretations of the French Revolution's radical phase of the Terror were thus formed at a time when the public manifestation of politically engaged groups of citizens were lauded by some and feared by others. Partisanship and opposition was not only a phenomenon in the realm of high politics but was increasingly taken to the streets. In the revolutionary and crisis-ridden atmosphere of the 179os, the pertinent and all too realistic question the Terror raised, then, was when this opposition would turn into civil disorder, anarchy, and in the most drastic case, lead to the destruction of the republic. ${ }^{13}$

Established historiography tends to present the representation of, and responses to, the radicalization of the French Revolution as a more or less static partisan (Republican-Federalist) affair, determined by domestic political allegiances. ${ }^{14}$ Indeed, the political landscape was increasingly determined by the emergence of the Federalist-Republican division. Yet, in what follows, I first try

of the American Revolution and fashioned the assumptions, compromises, and political alliances that defined the potential of American citizenship and the character of national politics in the antebellum United States'.

13 Cotlar, Tom Paine's America; S.P. Newman, Parades and the Politics of the Street: Festive Culture in the Early American Republic (Philadelphia, PA: University of Pennsylvania Press, 1997); J.L. Pasley, 'The Tyranny of Printers': Newspaper Politics in the Early American Republic (Charlottesville, VA: University Press of Virginia, 2001); Pasley, Robertson, and Waldstreicher, Beyond the Founders; D. Waldstreicher, In the Midst of Perpetual Fetes: The Making of American Nationalism, 1776-1820 (Chapel Hill, N.C.: University of North Carolina Press, 1997).

14 G.B. Nash, 'The American Clergy and the French Revolution', The Williamand Mary Quarterly22 (1965), pp.392-412;A.W. Robertson, “'Look on This Picture... And on This!" Nationalism, 
to convey a sense of the initial astonishment that struck so many Americans by just observing the astounding series of revolutionary events that were taking place in France. The terms of evaluation and ways of representing the radicalization of the French Revolution were more in flux than most historians have argued for. In addition, if present-day historians disagree about the nature of the Terror, and when it started, it is not surprising that among the American public of the 1790s, basing themselves on limited and coloured information, there was even less consensus about what distinguished radical politics from popular violence, or state-centred terror from emergency measures..$^{15}$ Paying attention to the step from initial response to more systematic reflection allows us to see what aspects of the Jacobin Terror were picked out or emphasized at what moments, and moreover, what implications were drawn from it to reconsider or confirm existing - ideals of citizenship at the time.

Many of the initial responses to the news of the radicalization and violence of the French Revolution tended to interpret it as a lamentable but unavoidable aspect of revolutionary struggle. Even a prominent Federalist publicist such as Noah Webster in 1793 initially interpreted the revolutionary violence within the grander scheme of 'a great and enlightened people struggling [...] to break down the feudal and hierarchical systems of despotism. ${ }^{16}$ Webster was fully aware of the tragedies that accompanied the upheaval in France and expressed his sympathy by calling upon his readers to 'drop a tear over the calamities that attend the French revolution'. At this point Webster still saw the calamities as 'inseparable from such great changes and events' and held that they could be ascribed to 'the treachery and perjuries of their perfidious domestic foes'. Webster's estimation of the fate of France was overall still optimistic, and he appeared willing to 'let reason smile at the prospect of peace in that new born republic'. He expressed the hope that 'when an energetic executive shall be constituted by the unbiassed suffrages of enlightened citizens, armed with the whole power of the nation', in the end things might turn out rather well. ${ }^{17}$

Localism, and Partisan Images of Otherness in the United States, 1787-1820', American Historical Review 106 (2001), pp. 1263-1280; Smelser, 'The Jacobin Phrenzy'.

15 On different interpretations of the Terror see, D. Andress, 'The Course of the Terror, 17931794', in: McPhee (ed.) A Companion to the French Revolution, pp. 293-310.

16 N. Webster, Effects of Slavery, on Morals and Industry (Hartford, CO: Hudson and Goodwin, 1793), p. 31.

17 Webster, Effects of Slavery, on Morals and Industry, pp. 31-32. 
Webster was not the only Federalist publicist to give the French Revolution the benefit of the doubt. In his 1793 Fourth of July oration in Boston, John Quincy Adams, son of Vice-President John Adams, and appointed ambassador to the Dutch Republic by the Washington administration in November that same year, naturally pictured the spirit of the French Revolution as originating from the 'principles' of American independence. Although turning his attention to the 'torrent of destruction' and the 'scaffold, smoking with the blood of the fallen monarch', John Quincy Adams still urged his listeners to 'rather indulge the pleasing and rational anticipation of the period when all the nations of Europe shall partake of the blessings of equal liberty and universal peace', as the 'the system of feudal absurdity has received an irrecoverable wound. 18 Equally, the politician and prominent historian of the American Revolution, David Ramsay, a supporter of the Federalists throughout the 179os, in his 1794 Fourth of July oration in Charleston, South Carolina, criticized 'the abettors of tyranny' who 'are anxiously looking for opportunities to discredit the new doctrines of the rights of man', as the 'eyes of the world are fixed on this country and on France'. Although he upheld the American nation as 'example' to other (European) nations, to show that 'genuine republicanism is friendly to order and a proper subordination in society' and 'that it is hostile to mobs and licentiousness of every kind', he had not given up on France. For France is 'daily proving, that a handful of citizens, fighting under the banners of liberty, is more than a match for an host of mercenaries, engaged in support of tyranny'. ${ }^{19}$

The sometimes bickering partisan perspectives on the course of the French Revolution of the mid and late 179os sometimes tend to overshadow the initial attitude of many Americans toward their new sister republic, namely that of detached astonishment. A perceptive comment in the Apollo; or, Chestertown Spy (Maryland) of May 31, 1793, shows this attitude:

We now touch on a new aera of a revolution which has been continually varying its form, and giving rise to fresh changes; a revolution which has astonished ordinary observers, by the novelty, magnitude, and rapid

18 J.Q. Adams, An Oration, Pronounced July 4th, 1793, at the Request of the Inhabitants of the Town of Boston (Boston, MA: B. Edes \& Son, 1793), p. 19.

19 D. Ramsay, 'The Oration of 1794', in: R.L. Brunhouse (ed.) 'David Ramsay, 1749-1815: Selections from His Writings', Transactions of the American Philosophical Society 55 (1965), Part IV, pp. 190-196, at p. 196. Ramsay's oration was delivered in St. Michael's Church at the request of the American Revolution Society and published afterwards. Ramsay was by then an established historian and author of The History of the Revolution in South-Carolina, From a British Province to an Independent State, 2 vols. (Trenton, N.J.: Collins, 1785) and The History of the American Revolution, 2 vols. (Philadelphia, PA: Aitken, 1789). 
succession of events; which has filled with horror the friends of humanity, by the crimes which it has produced, and the evils with which it has produced, and the evils with which it threatens humanity; and which has opened a new field of curiosity and speculation to the philosopher, while it baffles every effort of reasoning and conjecture. ${ }^{20}$

The quick succession of revolutionary events in particular perplexed the ordinary American observer. 'In France the gradations from despotism to limited monarchy; from limited monarch to republicanism; from republicanism to democracy; and from democracy to anarchy, have been extremely rapid', one commentator noted, 'and still the French go on in their wild career.' ${ }^{21}$ Indeed, even from a distance, the radicalization of the French Revolution seemed to 'accelerate time. ${ }^{22}$ Because of the astonishing pace and unpredictable chain of events, and because information was both partial and coloured, it should come as no surprise that a great many Americans for a while remained simply undecided on how to evaluate the turn the revolution in France had taken. 'Whether France is saved or ruined, is still problematical' and 'whether in the end, France will be blessed with a free constitution, securing to her the blessing of equal liberty [...] is a point to be developed in time', an 'American citizen' conceded in September 1794, just before the news of Robespierre's fall would reach the United States. Clearly, the author wrote, from the 'scenes of devastation, blood and carnage, the humane and enlightened citizens of America cannot but turn with indignant horror'. But it was still too early to turn one's back to France, he felt, "because the cause of France is ostensibly the cause of liberty, though, by all accounts, the nation never was in greater bondage than now; we view it is a glorious cause, and seem disposed to palliate the dreadful excesses by which it has been marked., ${ }^{23}$

Finally, it is important not to overlook an influential stream of Republican political millennialism coming from the pulpit that, until 1794-1795, interpreted the violence and radicalization of the French Revolution in providential and eschatological terms. ${ }^{24}$ The New York Presbyterian minister Samuel Miller, for instance, orated that, however 'this wonderful Revolution' may 'appear to

20 Apollo; or, Chestertown Spy (Chestertown, Maryland), May 31, 1793.

21 The South-Carolina State-Gazette (Charleston, South Carolina), November 25, 1794.

22 M.R. Hale, 'On Their Tiptoes: Political Time and Newspapers during the Advent of the Radicalized French Revolution, circa 1792-1793', Journal of the Early Republic 29 (2009), pp. $191-218$.

23 Greenfield Gazette (Greenfield, Massachusetts), September, 18, 25, 1794.

24 R.H. Bloch, Visionary Republic: Millennial Themes in American Thought 1756-1800 (Cambridge: Cambridge University Press, 1985), 150-187; N. Guyatt, Providence and the Invention 
be sullied by irreligion and vice, it is the cause of God'. ${ }^{25} \mathrm{He}$ did so in a sermon that was printed at the request of the (increasingly) democratic-republican Tammany Society, and printed by one of Massachusetts leading democratic printers and editor of the (democratic) New-York Journal, Thomas Greenleaf. Another typical sermon acknowledged the 'excesses' and 'cruelties' but declared that France may be 'excused' and that 'America cannot tax her with defect of friendship or candour'. ${ }^{26}$ As Ruth Bloch has suggested, this Republican millennialism, elaborated mostly by Baptists and Presbyterians, was not so much part of a partisan political debate but rather must be situated within popular culture. ${ }^{27}$ It was only from 1795 onwards, when the more conservative clergy vehemently turned against the French Revolution, that religious interpretations became politically inflammable. Nonetheless, earlier republican millennial responses to revolutionary violence contributed to a widely held view that the revolutionary violence in France was extraordinary and frightening, but excusable in light of the bigger picture.

From 1793 onwards, responses to the radicalization of the French Revolution became increasingly polarized. The execution of Louis XVI in January, and the declaration of war against Great Britain in February 1793, forced Americans to decide whose side they were on. ${ }^{28}$ The Washington administration's neutrality proclamation was decried loudly by democratic Republicans, and exacerbated the rift between Federalist Anglophiles and Republican Francophiles. In addition, the proclamation of the French Republic as well as the military successes of the French republican army prompted Americans throughout the country, from Charleston to New York and Lexington (Kentucky), to organize celebrations, feasts, and festivals. ${ }^{29}$ Thousands of ordinary citizens, white and black, women, and children, took to the streets, singing French songs, waiving French flags, and toasting to 'liberty and equality'. The festivities in Boston that began on January 24,1793 , were among the biggest public ceremonies of the decade and were reported extensively in numerous local and distant newspapers.

of the United States, 1607-1876 (New York: Cambridge University Press, 2007), pp. 146-150; Nash, 'The American Clergy and the French Revolution'.

25 S. Miller, A Sermon, preached in New-York, July 4th, 1793: Being the Anniversary of the Independence of America, at the Request of the Tammany Society, or Columbian Order (New York, N.Y.: T. Greenleaf, 1793), p. 32.

26 J. Lathrop, The Happiness of a Free Government, and the Means of Preserving It: Illustrated in a Sermon, Delivered in West-Springfield, on July 4th, 1794, in Commemoration of American Independence (Springfield, MA: Hutchins, 1794), p. 15.

27 Bloch, Visionary Republic, p. 154.

28 C.D. Hazen, Contemporary American Opinion of the French Revolution (Baltimore, MD: The Johns Hopkins press, 1897), pp. 254-256.

29 Newman, Parades and the Politics of the Street, pp. 120-151. 
Such festivities, one Massachusetts newspaper reported, welcomed 'every class of Citizen patriots', promising that social distinction would be 'abolished by the title of Citizens. ${ }^{30}$ To Federalists, who virtually never participated in them, these public manifestations constituted frightening scenes, especially in combination with the fierce attacks on the 'aristocratic' Washington administration. More radical elements, such as re-enactments of the beheading of the French king and the setting up of guillotines, even if sporadic, proved to them that the climate of opinion had hardened. ${ }^{31}$

At the same time, the influx of British, Irish, and Scottish middleclass radicals, many of them driven into exile by loyalist and government repression, strengthened the Federalist perception that the wave of European radicalism would cross the Atlantic, or had already done so. These 'transatlantic radicals' were soon caught up in the political controversies of the day. A significant number of them ended up in editorial positions, print business, and as members of democratic societies. ${ }^{32}$ Often ardent supporters of the French Revolution endorsing a Painite cosmopolitanism, they only heightened Federalist anxiety that what they saw as the excesses of radical popular democracy would spill over to American soil.

Finally, with the arrival of the French ambassador Edmond or 'Citizen' Genet in Charleston, South Carolina, on April 8, 1793, the radicalized French Revolution literally seemed to have landed on American shores. Genet was greeted enthusiastically in the overwhelmingly pro-French port-city Charleston. Welcome receptions and addresses were held in almost every town Genet visited on his way to the capital, Philadelphia, where his mission would consist of trying to win over the American government to aid the French in their war against the British. For reasons that have to do with his diplomatic inexperience, clumsiness, and overconfidence, Genet managed to offend the entire Federalist administration by ignoring its official proclamation of neutrality. The Washington administration denied all Genet's requests to equip and allow American and French ships to carry out privateering raids on British ships, which would amount to a war declaration against Britain. Deeply frustrated, Genet then appealed directly to the American people, a move that was particularly bold in light of his close connections with democratic-republican societies in some parts of the country. Beginning on 31 July, 1793, a series of articles entitled

30 Massachusetts Mercury (Boston, Massachusetts), January 17, 1793, as cited in: Newman, Parades and the Politics of the Street, p. 127.

31 R.H. Cleves, The Reign of Terror in America: Visions of Violence from Anti-Jacobinism to Antislavery (New York: Cambridge University Press, 2009), p. 65.

32 M. Durey, Transatlantic Radicals and the Early American Republic (Lawrence, KS: University Press of Kansas, 1997). 
'No Jacobin', written unanimously by Secretary of the Treasury Alexander Hamilton appeared in Philadelphia newspapers. In these articles Hamilton frontally attacked Genet who 'has threatened to appeal from The President of the United States to the People'. He accused Genet of 'electrifying the people', of 'popular intrigue'; his actions were 'violations of our sovereignty', as he was trying to raise 'men [...] against the will of the government'. On top of that, as 'public newspapers' have made known, Genet was now an 'acknowledged member of a political Association'.33 In the years 1793-1794, when the country was receiving more dreadful reports on the Jacobin democratic experiment on the other side of the ocean, the Federalist reflection on the Terror shifted towards the very 'political associations' Hamilton was talking about.

\section{Political Societies, Faction, and the Limits of Democratic Citizenship}

Between 1793 and 1795, more than 40 democratic-republican societies were formed throughout the United States. ${ }^{34}$ The first, pioneering German Republican Society and the larger Democratic Society of Pennsylvania were founded in the nation's capital, Philadelphia. Soon democratic-republican societies sprang up in other major east-coast cities, while a considerable number were established in rural counties too. The founding document of the prominent Democratic Society of Pennsylvania declared that it was instituted 'with a view [...] to cultivate a just knowledge of rational liberty, to facilitate the enjoyment and exercise of our civil Rights, and to transmit, unimpaired, to posterity the glorious inheritance of free Republican Government'. These goals were to be achieved by means of 'a constant circulation of useful information, and a liberal communication of republican sentiments', the 'best antidotes to any political poison.' ${ }^{35}$ Members of democratic-republican societies were by and large drawn from the middle and lower classes, among them shopkeepers, artisans,

33 H.C. Syrett (ed.) The Papers of Alexander Hamilton, 27 vols. (New York, N.Y.: Columbia University Press, 1961-1987), vol. 15, 'No Jacobin no. 1', 31 July, 1793, p. 145; 'No Jacobin no. 5', 14 August, 1793, pp. 244, 246; 'No Jacobin no. 7', 23 August, 1793, p. 268. The articles appeared in Dunlap's American Daily Advertiser (Philadelphia, Pennsylvania) and were reprinted in several other newspapers.

34 E.P. Link, Democratic-Republican Societies, 1790-180o (New York, N.Y.: Columbia University Press, 1942); P.S. Foner, The Democratic-Republican Societies, 1790-180o: A Documentary Sourcebook of Constitutions, Declarations, Addresses, Resolutions, and Toasts (Westport, CT: Greenwood Press, 1976).

35 Independent Gazetteer (Philadelphia, Pennsylvania), July 13, 1793. 
and merchants, but also workingmen and mechanics. Local politicians, lawyers, and printers often constituted the leadership of the societies. ${ }^{36}$

By regularly organizing public or semi-public discussion meetings, celebrations, and feasts, as well as by publishing pamphlets, addresses, and newspaper articles, democratic-republican societies aspired to create an engaged and informed citizenry. Drawing on a classical-republican vocabulary, the democratic-republican societies deemed the established Federalist government deeply 'corrupted. ${ }^{37}$ Consequently, as the German Republican Society of Philadelphia put it, 'In a republican government it is a duty incumbent on every citizen to afford his assistance $[. .$.$] by his advice and watchfulness, that its principles$ may remain incorrupt; for the spirit of liberty, like every virtue of the mind, is to be kept alive only by constant action' ${ }^{38}$ Identifying themselves with examples set by the revolution in France, democratic-republican societies conceived of themselves as representatives of the people. As an 'Address to the Citizens of the United States' in the democratic Boston Argus in May 1793 stated: 'the partizans of Louis Capet alledge that clubs and mobs do every thing, against law, and the voice of the nation; but we believe, that those clubs and mobs are the nation itself. ${ }^{39}$ Democratic-republican societies believed that a healthy republic requires a vibrant and more open public sphere in which citizens play a politically active role; and they saw the platform of a democratic-republican society as the ideal 'mediating institution' to attain that goal. ${ }^{40}$

The democratic-republican societies' heightened presence in the American public sphere aroused suspicion and drew heavy criticisms from Federalist publicists and politicians alike. It was certainly not the case that Federalists discarded voluntary citizen associations tout court. The revolutionary political associations of the 1770s, such as Sons of Liberty and the Corresponding Societies, by which democratic republicans were undoubtedly inspired, were held in high esteem. Federalists duly acknowledged the need for, and value of, such associations in times of revolution. However, under the new constitutional order, there was no place for associations that in their eyes only sought to undermine,

36 Foner, The Democratic-Republican Societies, pp. 7-8; M. Schoenbachler, 'Republicanism in the Age of Democratic Revolution: The Democratic-Republican Societies of the 179os', Journal of the Early Republic 18 (1998), pp. 237-261.

37 Schoenbachler, 'Republicanism in the Age of Democratic Revolution'.

$38 \quad$ National Gazette (Philadelphia, Pennsylvania), April 13, 1793.

39 The Argus (Boston, Massachusetts), May 24, 1793.

40 'Mediating institution' is Albrecht Koschnik's term, see Koschnik, 'The Democratic Societies of Philadelphia', p. 617. See also his 'Let a Common Interest Bind Us Together'. Associations, Partisanship, and Culture in Philadelphia, 1775-1840 (Charlottesville, VA: University of Virginia Press, 2007). 
or worse, overturn established authorities. A further disconcerting novelty of the democratic-republican societies was that they did not shy away from public controversy and actively engaged in national and international political debates. They moreover sought publicity through a national network of newspapers. Benjamin Franklin Bache, the editor of one of the principal democratic opposition newspapers, the Aurora General Advertiser, was also one of the leading members of the Democratic Society of Pennsylvania. Through men like Bache, democratic-republican societies became connected through a network of newspapers and correspondents that passed on addresses, resolutions, and articles to each other, which led one worried Federalist to decry that the democratic societies have 'invested themselves with a disproportionate degree of power' and have become' the monopolizers of public opinion, and public influence.'41

Democratic-republican societies self-consciously launched themselves within the ambit of transatlantic revolutions. The 'Principles, Articles \& Regulations' of the Democratic Society of Pennsylvania, for example, commenced with the statement that the 'rights of man' have been 'clearly developed by the successive Revolutions of America and France'. Closely affiliated with the French Society of the Friends of Liberty and Equality (or French Patriotic Society), the Philadelphia societies played an important part in the grand reception and dinner to welcome Citizen Genet in late May 1793. 'The table was decorated with the tree and cap of liberty, and the French and American flags', the National Gazette reported. French songs were sung and toasts were drunk on 'Liberty and Equality', the 'Union and perpetual fraternity between the people of France and the United States' as well as on the 'liberty and success of the Dutch patriots - Généreux frères de la république / Amis des Bataves patriotiques. ${ }^{42}$

This celebration of the revolution of their Batavian frères proved to be slightly premature. But two years later, newspapers in Pennsylvania, New Hampshire, New York, and Maryland reported extensively on a 'civic festival' in Philadelphia celebrating the victorious Batavian revolutionaries. A large gathering of American, Dutch, and French citizens, saluted by gunshots, paraded 'with the three flags of the republics' to the French embassy where 'an altar was erected on which the Statue of Liberty was placed'. An address was held by a French citizen proclaiming that 'the soldiers of Liberty are everywhere triumphant'. He then proposed that everyone present to swear an oath in order to

$41 \quad$ Federal Orrery (Boston, Massachusetts), March 25, 1795.

42 National Gazette (Philadelphia, Pennsylvania), May 25, 1793. Reprinted in The Argus (Boston, Massachusetts), June 4, 1793 . 
'cement among us the triple alliance of three republics' and to 'maintain political equality'. The Dutch, he went on, 'retain unimpaired the right of changing or amending their constitution'. The Minister of France, delighted by the spectacle, exclaimed: 'Long live the French Republic! - Long live the Republic of the United States! - Long live the Batavian Republic!' And while 'the air resounded with the cries of Long Live the Three Republics', 400 citizens adjourned to a nearby hotel where they feasted on a 'sumptuous repast'. 43

As was the case in Philadelphia, democratic-republican societies throughout the country would come to play an important part in organizing and shaping national and other public festivities celebrating the French - and occasionally the Batavian - Revolution. ${ }^{44}$ Next to declaring their brotherhood with French democrats, affiliated democratic newspapers reported regularly on the proceedings of Irish and British radical clubs, as well as the French Jacobin clubs. In doing so, members of democratic-republican societies, some of which adopted the French address of 'citizen' (instead of 'Sir'), were stimulated to imagine themselves as part of a larger transatlantic citizen emancipation movement. ${ }^{45}$

The democratic-republican societies voiced opinions that broadly overlapped with those of Madison, Jefferson, and the more mainstream Republican opposition (anti-British rhetoric, opposition to Hamilton's financial program, and disdain of Federalist elitism). Yet they largely developed alongside the national Republican leadership. Local public officials and politicians could sometimes be fully immerged in societies' activities and there are some examples of societies actively supporting the candidacy of their own members for state legislatures, and in one case for Congress. But on the level of national politics, Republicans were generally extremely reluctant to publicly sympathize with the societies, especially after democratic-republican societies were being associated with rebellion and sedition. ${ }^{46}$

43 Aurora General Advertiser (Philadelphia, Pennsylvania) April 20, 1795. The article was reprinted in: Philadelphia Gazette (Philadelphia, Pennsylvania), April 20, 1795; Dunlap's American Daily Advertiser (Philadelphia, Pennsylvania), April 21, 1795; Federal Intelligencer (Baltimore, Maryland), April 23, 1795;

Herald (New York, New York), April 25, 1795; New-Hampshire Gazette (Portsmouth, New Hampshire), May 5,1795 .

44 Newman, Parades and the Politics of the Street, pp. 92, 143; Waldstreicher, In the Midst of Perpetual Fetes, pp. 126-141.

45 Koschnik, 'The Democratic Societies of Philadelphia', p. 621.

46 S. Wilentz, The Rise of American Democracy: Jefferson to Lincoln (New York, N.Y.: Norton, 2006), pp. 59-61. 
Federalists considered the opposition of Republican politicians as a challenge to their political ideal of an elected natural aristocracy harmoniously deliberating the means to attain the common good. The democratic-republican societies' appearance in the national public sphere confronted them with a radical model of democratic citizenship outside the boundaries of what they considered to be a sound representative system of government. Confronted with this challenge that was of an entirely different nature than the top-down politics of the Republican gentry, Federalist interpretations of the radicalization of the French Revolution came to focus on the phenomenon of clubs and the role they played in the Terror of $1793^{-1794}$. Americans had decried the 1792 September massacres in and around Paris prisons somewhat vaguely as revolutionary violence. But over the course of 1793 and 1794 the role of Jacobin clubs, Parisian popular militia, and central committees, as well as the GirondinMontagnard split, mass prosecutions and executions were reported in greater detail in American newspapers. Accordingly, Federalists began to see and portray the democratic-republican societies through the lens of Jacobin clubism.

The large-scale violent uprising in western Pennsylvania that broke out in the Summer of 1794 over the national government's levy of excise taxes on distilled liquors, which grew into a frontier-wide movement better known as the 'Whiskey Rebellion', aggravated suspicion toward the societies up to the point of outright hostility. ${ }^{47}$ The rebellion, seemingly spreading unchecked came to a climax in mid-July 1794 when 7,000 protesters assembled east of Pittsburgh. It impelled President Washington to send an army of 13,000 militiamen to crush the rebels, an army almost the size of the Continental Army he had under his command at the time of the American Revolutionary War. It was the largest mobilization of national troops against the largest local armed resistance movement against federal law between the revolutionary wars of independence and the Civil War.

The Whiskey Rebellion gave the Federalist fears about the societies' socially disruptive potential immediate urgency and provided them with a sharpened set of argumentative weapons to attack the societies' conception of radical democratic citizenship. In December 1794, Robert Treat Paine Jr's Boston Federal Orrery, for example, after lashing out at the 'despotism of Jacobin Clubs in France', maintained that the Whiskey Rebellion was an act of defiance to constituted government analogous to Jacobin rioting. It was 'sacredly true' to his stretching back into the 1770 and 1780 s, see Bouton, Taming Democracy. 
mind, 'that the Jacobin clubs of Paris' did nothing but 'oppose the constituted authority of the French Republic'. The American democratic-republican societies, he went on, '[n]ot being able to succeed in Congress, as their brother Jacobins did in the convention in Paris, have excited an insurrection in Pennsylvania:48 In the Columbian Centinel, one of the leading Federalist newspapers of the day, another critic depicted them as '[a]ssociations of discontented ambitious men, assembling under the disguise of night in taverns and private houses, with a pretence of redressing grievances' ${ }^{9} 9$ Their alleged secrecy was often associated with the partisan 'undemocratic' nature of French political clubs, as another 'American citizen' in a Massachusetts newspaper held. For 'how these private societies (separated in their proceedings as they commonly are, by bolts and bars, from the knowledge of their fellow citizens, without the suffrages of their countrymen as their basis, and in no way accountable to them for their conduct) how these come by their influence, or whence they derive their existence, we know not'. Clearly ' $\mathrm{t}]$ he benevolent heart must turn indignant from the sight, and our Democratic Societies themselves, would, I hope, shudder at the thought of introducing such scenes in America, as have been the fruits of Jacobinism in France.' ${ }^{50}$

The association of the democratic-republican societies with both the Whiskey Rebellion and the Jacobin clubs in France - and by implication, the Terror - became a powerful charge against unbridled citizen political activism. Noah Webster's The Revolution in France, considered in Respect to its Progress and Effects, published in 1794, was perhaps the most elaborate analysis of what he considered the violent derailment of the French Revolution. He urged his readers to take the lessons of the French excesses to heart, for 'The revolution of France, like that of Rome, is fruitful in lessons of instruction' and 'may be of great use to the United States of America.'. ${ }^{51}$ One crucial lesson the New Yorkbased editor of the American Minerva drew from the recent history of France, was the inherent danger of political clubs, those 'private societies of men, who are self-created, unknown to the laws of the country, private in their proceedings, and perhaps violent in their passions'. Such secluded political associations could only lead to 'party spirit' and 'faction'. And faction, Webster believed,

$48 \quad$ Federal Orrery (Boston, Massachusetts), December 25, 1794.

49 Columbian Centinel (Boston, Massachusetts), August 30, 1794.

$50 \quad$ Greenfield Gazette (Greenfield, Massachusetts), September 18, 25, 1794.

$5^{1} \quad$ [N. Webster], The Revolution in France, considered in Respect to its Progress and Effects. By an American (New York, N.Y.: G. Bunce, 1794), pp. 40-41. 
means ultimately 'death to the existing government. The history of the Jacobins is the most remarkable illustration of this truth., ${ }^{52}$

According to Federalists such as Webster, politics ought to be the business of eminent gentlemen who should stay clear from the swings of public passion. Looking at France, the eradication of aristocratic and noble titles was without question justified. But that titles of 'civility and respect' such as 'monsieur' and 'madame' were to be subject to legislation and substituted for the 'awkward term citizen' was a grave sign in Webster's estimation. In 'their zeal for equalizing men, the Convention forgot that certain kinds of inequality between men are, in fact, most natural in a civil society', most importantly, the kind of inequality that arises out of 'the merit of eminent services, age, talents, wealth, education, virtue'.53 'Such inequality is generally a most visible aspect of distinction in public life', and hence commands a kind of respect that in turn brings forth a 'natural aristocracy' of men of influence. 'Experience and severe calamities', on the other hand, have shown 'that government immediately in the hands of the people, of citizens collected without law, and proceeding without order, is the most violent, irregular, capricious and dangerous species of despotism'. The recent French experiment with popular democracy showed 'that a Paris mob is not to govern France'. Representative government itself had become a travesty, for an assembly of representatives ought not to be 'a company of stage-players, whose speeches are to be regulated by the hisses and acclamations of a promiscuous collection of men in the galleries. ${ }^{4}$ Another Federalist publicist, William Willcocks, projected Webster's analysis of Jacobin clubs onto the activities of 'our democrats'. 'Their professed object', Willcocks opined in a piece that appeared in the Federal Orrery and the American Minerva, is to 'censure, or applaud, correct, and control the measures of the legal representatives of the commonwealth - in other words to make parties in congress and throughout the state'. Democrats had already started to 'artfully [...] affiliate members of congress', Willcocks warned, and if no measures were taken, it would not take long, given the activitities of the 'mother society' in Philadelphia, to 'see the effects of mobs and the dreadful machinations of seditious, or ambitious men.' 55

52 [Webster], The Revolution in France, pp. 41, 47-48. Cf. The Minerva (New York, New York), November 27, 1794: '[T] he Jacobin Society has been the central point of union for the mentigers who have torn the Republic in pieces, and the vermin that gnawed upon its vital during the reign of Robespierre'.

53 [Webster], The Revolution in France, pp. 27-28.

54 [Webster], The Revolution in France, pp. 70-71.

55 Federal Orrery (Boston, Massachusetts), March 23, 1795. 
That the democratic-republican societies were associated with the Whiskey Rebellion and Jacobin practices was not entirely without grounds. The Democratic Society of Pennsylvania was a declared opponent of excise taxes. Another local western Philadelphian popular society filed petitions on behalf of discontented western Pennsylvanian settlers, an act which in the midst of a national crisis was easily dismissed as treason. ${ }^{56}$ The rebels, moreover, dubbed by the Gazette of the United States as 'sans culottes of Pittsburgh', were known to praise the example of France and set up guillotines. ${ }^{57}$ In early 1795, the Boston democratic-republican society declared that 'if to advocate the right of Free Inquiry and Opinion, and to wish success to the cause of equal Liberty every where, compose the character of Jacobins, we avow ourselves JACOBINs', while the Charleston Democratic Club petitioned in Paris to become a member of the French Jacobin Club. ${ }^{58}$ For a while, it seemed to many Federalists, democratic-republican societies sought to plunge the United States in chaotic depths similar to those of revolutionary France.

Eventually, democratic-republican societies were not able to withstand the Federalist counterattack, especially once they were condemned by President Washington whose popularity still exerted a powerful influence. About the Whiskey Rebellion, there was no doubt on President Washington's mind: 'I consider this insurrection as the first formidable fruit of the Democratic Societies'. If not counteracted, these societies were able to 'shake the government to its foundation', Washington wrote in a letter to Virginia governor Henry Lee, and 'destroy the best fabric of human government and happiness'.59 In a September 1794 proclamation on the Whiskey Rebellion, Washington publicly denounced 'certain self-created' societies. The allegations of Federalists did not pass unchallenged. Several spokesmen of the democratic societies publicly disassociated themselves from 'means unwarrantable and unconstitutional' or expressed to 'feel sore at the imputation that the insurrection in Pennsylvania is ascribable to the Jacobin Clubs. ${ }^{\prime 0}$ But it could not prevent that arguments against them, and in a broader sense against popular democracy or 'mob rule', could be fruitfully deployed by inserting the spectre of Jacobin radicalism into these allegations. In the end, the democratic-republican societies succumbed

$5^{6} \quad$ Slaughter, The Whiskey Rebellion, pp. 161-164.

57 Wood, Empire of Liberty, pp. 187-188.

58 As cited in: Wilentz, The Rise of American Democracy, p. 56.

59 Letter from George Washington to Henry Lee, August 26, 1794, in: The George Washington Papers at the Library of Congress 1741-1799, ed. John C. Fitzpatrick, available at: http:// lcweb2.loc.gov/ammem/gwhtml/gwhome.html (date of access: December 19, 2013).

6o Dunlap and Claypoole's American Daily Advertiser (Philadelphia, Pennsylvania), December 12, 1794; Andrews's Western Star (Stockbridge, Massachusetts), October 28, 1794. 
to the association with the Whiskey Rebellion, the torrent of public attacks, the dissociation of Republican leaders, and internal division. By 1796 most societies had dissolved.

The rise of democratic-republican societies, the egalitarian and participatory citizenship model they represented and propagated, and their public identification with the principles of revolutionary movements in Europe, was surely a moment of transatlantic convergence. At the same time, the writings of Federalists such as Robert Treat Paine Jr., Willcocks, and Webster were part of a broader Federalist effort to defend a model of deferential, passive citizenship, a model that bears striking similarities to the French Thermidorian model of citizenship. ${ }^{61}$ Both were grounded in a concept of an undivided citizenry. As an open letter 'to the Democratic Society of Philadelphia' that appeared in the Columbian Centinel and American Minerva in May 1794 put it: '[I]n Ameri$c a$, where there is but one order [...] the people - what use can there be in a small club of these same people? The great body of people in America constitutes one immense popular society'.62 Their model was, furthermore, premised on the high ideal of the 'independent', impartial, citizen. As Webster explained, when people become member of a political club, 'they lose their individual independence of mind [...] they lose their impartiality of thinking and acting; and become the dupes of other men. The moment a man is attached to a club, his mind is not free: He receives a biass from the opinions of the party'. The problem was not the existence of private associations as such: 'Private associations of men for the purposes of promoting arts, sciences, benevolence or charity are very laudable, and have been found beneficial in all countries'. But this is where Webster and many other Federalists drew the line. The great danger lies in the politicization of such societies. Then the 'private attachment' of their members is converted 'into an instrument of political warfare'; then 'an independent freeman is converted into a mere walking machine, a convenient engine of party leaders'.63

Finally, the Thermidorian and Federalist conceptions of citizenship in a modern republic entailed that, outside elections, citizens ought not to interfere with the representatives' 'free agency', as the Federal Orrery put it. This was 'the essential privilege of their constituents to give them - and their bounden right and duty to maintain and exercise. ${ }^{64}$ For both Federalists and Thermidorians, the Jacobin and democratic-republican societies constituted unconstitutional

\footnotetext{
$61 \quad$ See Chapter 4.

62 Columbian Centinel (Boston, Massachusetts), May 2, 1794.

63 [Webster], The Revolution in France, pp. 47-50.

64 Federal Orrery (Boston, Massachusetts), March 23, 1795.
} 
platforms of citizen activism and unsound forms of public will formation. They divided the body of citizens, conceived as a unified whole, instead of representing it, and prevented wise legislators to rule independently.

\section{Anti-Jacobinism and the American Citizenship Model}

During the second half of the 1790 s, and in particular during the period 1798 1800, American discourse surrounding the Terror took on new dimensions, as the political climate grew increasingly antagonistic. One of the key factors that accounts for this growing hostility was the souring relationship between the French and American republics, and its repercussions for domestic public temperament. Particularly explosive in this context was the so-called 'XYZ Affair'. When in May-June 1797 the United States and France almost got into a naval war, the American administration under President John Adams sent a diplomatic envoy to start negotiations with the French Directory's foreign minister Talleyrand. Judging from the documents disclosed by Adams in April the next year, the American diplomats had been humiliated and threatened by French representatives of Talleyrand (referred to in the documents as ' $\mathrm{X}$ ', ' $\mathrm{Y}$ ', and ' $\mathrm{Z}$ '), who had demanded for outstanding debt payments, bribes, and forced loans to the French Directory. Pro-French Republicans, both moderate and more democratic, were put in a particularly awkward predicament, as one of the French representatives had referred to the 'friends of France', suggesting that there was a subversive group of Americans supporting France and undermining the American government from within. The extensive reporting of newspapers on the XYZ Affair caused a national public outrage and led to a massive rallying behind the Federalist administration. ${ }^{65}$ On their return, the American diplomats were welcomed as heroes. Once popular French songs were despised and exchanged for 'Hail Columbia' and Robert Treat Paine Jr's immensely popular 'Adams and Liberty'. President Adams himself received hundreds of supportive petitions drawn by meetings from all over the country, including southern Republican states, asking for stern measures against France. As historian Douglas Bradburn has demonstrated, these petitions articulated a powerful anti-French, nationalist sentiment. ${ }^{66}$ The Federalist press,

65 M.R. Hale, "Many who wandered in the darkness": The Contest over American National Identity, 1795-1798', Early American Studies 1 (2003), pp. 127-175; T.M. Ray, “Not One Cent for Tribute": The Public Addresses and American Popular Reaction to the XYZ Affair, 17981799', Journal of the Early Republic 3 (1983), pp. 389-412.

Bradburn, The Citizenship Revolution, pp. 150-162. 
moreover, buzzed with rumours that French spies, together with American collaborators, were cooking up plans to turn the United States into a puppet republic, just as France had subjected the Dutch, Italian, and Swiss republics. When Congress issued a quasi-war declaration against France, the United States entered a state of war-like mobilization. In some towns voluntary progovernment militias began to march the streets. Occasionally, fights between democratic Republicans and anti-French crowds broke out. For a while, Republicans seemed to have lost the public's favour. ${ }^{67}$

Arguably, the XYZ Affair and the quasi-war with France only represented a temporary political blowback for (Jeffersonian) Republicans. The deeper and more permanent significance of French-American hostilities was that it proved to Federalists, as well as a to growing numbers of Republicans, that France could no longer be considered a 'benevolent sister republic'.

The polarization between Republicans and Federalists took on even more extreme forms when the threat of war with France motivated Congress in the summer of 1798 to pass four acts known as the Alien and Sedition Acts. These acts severely restricted the naturalization of foreigners, as well as the rights of non-naturalized immigrants. It was the last act that enflamed Republican publicists most, as it made punishable by law 'false, scandalous and malicious writing or writings against the United States [...] with intent to defame the said government [...] or to excite [...] the hatred of the good people of the United States'. ${ }^{68}$ While Federalists saw in it a means to protect the country from seditious 'Jacobin' democratic editors and publicists who tried to stir up opposition, and in their worst fantasies, overthrow civil government, Republicans widely decried the acts as a blatant violation of the constitution and as an antirepublican attack against the freedom of the press. ${ }^{69}$

On a cultural, intellectual, and also conceptual level, the distancing of Americans from the 'French' model of political order and citizenship was also due to a number of other factors. First of all, after the fall of Robespierre more and more detailed information about the Terror - although often extremely biased and hardly accurate - reached the United States and found its way into American newspapers. ${ }^{70}$ Numerous accounts of the Terror from both France and other European countries were translated and brought on the American

\footnotetext{
67 Ray, “Not One Cent for Tribute": The Public Addresses'; Wood, Empire of Liberty, pp. 239-247.

68 'Appendix. The Alien and Sedition Laws', in: Smith, Freedom's Fetters, pp. 435-442, at p. 442.

69 Bradburn, The Citizenship Revolution, pp. 168-205.

$70 \quad$ Albany Gazette (Albany, New York), March 20, 1795.
} 
market. ${ }^{71}$ To these reports about the Terror, Federalist editors and printers eagerly supplied their comments that American citizens should by now be convinced of the 'infernal' nature of the French regime. The American Minerva of November 27, 1794, for example, told its readers that 'we have waited patiently for authentic proofs, which it was certain the experience of France would furnish, of all the tyrannies, the villaines, and the crimes which the Jacobins have, for two years past, been committing in that fine country'. The American Minerva underscored that ' $\mathrm{w}$ ] $\mathrm{e}$ always applauded the revolution' and 'admired the spirit that actuated the real republican of France'. However, given the news from France, it was important to make a 'distinction, which is certainly just, between the regeneration of the government of France, an object desirable to all good men' and 'the factious violent means of conducting the revolution'. According to the New York newspaper, it all added up to the 'evidence of the state of anarchy that has prevailed in France, and the tyranny of the popular leaders.' 72

In addition, from 1795 onwards conservative American clergymen increasingly represented and interpreted the Jacobin regime, and the French Revolution more generally, as dangerously irreligious. Reports of dechristianization and the cult of the Supreme Being were taken as signs that French Jacobins were waging a war not only on civil liberties, but on the very religious foundation of moral and political order. The publication of Thomas Paine's Age of Reason in 1794 (part I) and 1795 (Part II) had alarmed the American, and especially the New England clergy. The Age of Reason saw as many as seventeen editions in the United States, and found a broad readership among democratic Republicans, deists, and students. ${ }^{73}$ It incited dozens of heated responses from

71 Such as P.E. Béraud, The Siege of Lyons (During the Dictatorship of Robespierre), trans. From the French (Stockbridge, MA: Loring Andrews, 1795); H. Riouff, Revolutionary Justice Displayed; or an Inside View of the Various Prisons of Paris, under the Government of Robespierre and the Jacobins. Taken Principally from the Journals of the Prisoners Themselves, trans. from the French (Philadelphia, PA: 1796). See Cleves, The Reign of Terror in America, p. 87 .

72 American Minerva (New York, New York), November 27, 1794.

73 Gary Nash also mentions a number of other translated unorthodox deistic and naturalistic writings that were published in ${ }^{1795^{-1}}{ }^{1796}$, such as Constantin François de Chassebœuf, comte de Volney's Common sense; or Natural Ideas Opposed to Supernatural (New York, s.n., 1795); idem, The Law of Nature, or Principles of Morality, deduced from the Physical Constitution of Mankind and the Universe (Philadelphia, PA: Stephens and Baily, 1796); Paul von Holbach's Christianity Unveiled; being, an Examination of the Principles and Effects of the Christian Religion (New York: Columbian Press, 1795); William Godwin, Enquiry Concerning Political Justice (Philadelphia, PA: Bioren and Madan, 1796); and Voltaire's Philosophical Dictionary (New York: J. Fellows \& E. Duyckinsk, 1796). Nash, 'The American 
the conservative clergy who were anxious that Painite deism would spread among the lower ranks of society. The effect was that in a short period of time, influential clergymen heaped together Jacobinism, transatlantic Painite radicalism, and atheism (or deism), as presenting one colossal threat to the moral and political order at the time. ${ }^{74}$ Federalist newspapers eagerly joined their ranks. A telling example of how Federalist newspapers tried to mark Jacobins as godless anarchists was the satirical 'Jacobin Creed' that appeared in at least seven (national and local) newspapers in New Hampshire, Massachusetts, Pennsylvania and, South Carolina, in the summer and fall of 1796 . According to the piece, Jacobins

believe there is no God but nature; not religion but revolution (alias regeneration;) no just government but anarchy; and no civil liberty where the guillotine is not erected.

believe Robespierre was the great apostle of liberty

believe that war is better than peace, confusion than order, terror than mildness, and the guillotine than all the courts of justice extant.

believe that the United States of American ought to be under the direction of my brothers in France ${ }^{75}$

Such depictions of 'Jacobins' were not strictly comments on the Terror. Rather, the Terror was presented as part, or rather the apex, of a broader antiEnlightenment critique. This critique was not pointed against the Enlightenment per se - many Federalists identified themselves as heirs to a 'pragmatic' Enlightenment associated with such people as Benjamin Franklin - but rather against its specific French deistic (or atheistic) variant. ${ }^{76}$ The 'Jacobin' was the antithesis of the ideal of the American citizen: God-fearing and law-abiding; a supporter of order and civil liberties, and on his guard against cosmopolitan radicals united in secretive societies. ${ }^{77}$

Clergy and the French Revolution', pp. 392-412; H.F. May, The Enlightenment in America (New York: Oxford University Press, 1976), pp. 226, 263-264.

74 May, The Enlightenment in America, pp. 252-277.

75 The New Hampshire and Vermont Journal: Or, The Farmer's Weekly Museum (Walpole, New Hampshire), July 12, 1796; Gazette of the United States (Philadelphia, Pennsylvania), July 21, 1796; Eagle (Hanover, New Hampshire), July 25, 1796; Carlisle Gazette (Carlisle, Pennsylvania), August 3, 1796; Herald or, the New Daily Advertiser (Charleston, South Carolina), 8 August, 1796; Sun (Dover, New Hampshire), September 28, 1796; Rural Repository (Leominster, Massachusetts), October 13, 1796.

76 May, The Enlightenment in America, pp. 252-270.

77 Cf. Smelser, 'The Jacobin Phrenzy'. 
As public opinion was turning against France and conservative clerics were caught up in a battle against atheism, a wave of (mostly British) anti-Jacobin conspiracy literature flooded the country. The Edinburgh philosophy professor John Robison's Proofs of a Conspiracy against all the Religions and Governments of Europe, the French Jesuit Abbé Barruel's Memoirs Illustrating the History of Jacobinism, and the Scottish political economist William Playfair's History of Jacobinism attracted a large reading public and were soon embraced and exploited by the conservative American clergy. ${ }^{78}$

These works shared a number of broad characteristics. They related of the existence of a transatlantic conspiracy of Masonic Illuminati stretching back to Bavaria in the $1770 \mathrm{~s}$ in which French philosophes and politicians figured prominently. Next, the Terror was presented as the logical outcome of the atheistic philosophy professed by a network of secret societies. More frightening still, the Jacobin tentacles reached deeply into American society. No one was more important in voicing and disseminating anti-Jacobinism in the late $1790 \mathrm{~s}$ than the British publicist, printer, and bookseller William Cobbett. Under the pseudonym 'Peter Porcupine', Cobbett between 1795 and 1797 published a number of vitriolic pamphlets against 'American Jacobins', many of which went through multiple editions, with such telling titles as $A$ Bone to gnaw for the Democrats. A History of American Jacobins, or The Bloody Buoy, thrown out as a Warning to the Political Pilots of all Nations. Or, a Faithful Relation of a Multitude of Acts of Horrid Barbarity, such as the Eye never witnessed, the Tongue never expressed, or the Imagination conceived, until the Commencement of the French Revolution. In March 1797, Cobbett began his own Porcupine's Gazette in which he continued his attacks against democratic newspapers editors. Porcupine's Gazette soon became one of the most-read newspapers of the country and would be often excerpted by Federalist newspapers. Finally, Cobbett owned a bookshop in the centre of Philadelphia from where he would distribute and reprint bestselling titles including Robison's Proofs of a Conspiracy, Barruel's Memoirs, and Playfair's History of Jacobinism, as well as Aufrere's Cannibal's Progress relating of the atrocities committed during the French invasion of German states. By 1798, Cobbett was by far the most notorious anti-Jacobin

78 J. Robison, Proofs of a Conspiracy against all the Religions and Governments of Europe (Philadelphia, PA: Dobson and Cobbet, 1798); Abbé Barruel, Memoirs Illustrating the History of Jacobinism (Hartford, CO: Hudson \& Goodwin, 1799); W. Playfair, The History of Jacobinism: Its Crimes, Cruelties and Perfidies: Comprising an Inquiry into the Manner of Disseminating, under the Appearance of Philosophy and Virtue, Principles which are Equally Subversive of Order, Virtue, Religion, Liberty and Happiness; with an Appendix by Peter Porcupine, Containing a History of the American Jacobins, commonly denominated Democrats (Philadelphia, PA: W. Cobbett, 1796). 
voice in the American Republic, extremely popular among Federalists, despised by Republicans, also as the enemy-you-love-to-hate. ${ }^{79}$ Although some historians have portrayed Cobbett as an ultra-Tory and a British maverick, remaining largely outside serious political debate, more recently it has been argued that 'Cobbett's anti-Jacobinism had a profound impact on American politics. ${ }^{80}$ Well versed in the art of often biting (and sometimes comical) political satire, Cobbett's rhetoric was often hyperbolic. He also managed to alienate himself from more mainstream Federalists, because of his unashamedly proBritish stance and his attacks on other major Federalist newspaper editors, including Noah Webster and Benjamin Russell. Central, if toned-down, elements of his extreme anti-Jacobinism, however, became part of mainstream Federalist rhetoric as expressed by publicists such as Robert Treat Paine Jr. and the Federalist religious establishment.

The apex of Federalist clerical anti-Jacobinism, echoing Cobbett's rhetoric, was a sermon delivered by Jedidiah Morse, a Congregational minister from Massachusetts, in the Spring of 1798. Citing and summarizing Robison and Barruel, Morse drew an explicit connection between international Jacobin conspiracies, and 'men among us, so lost to every principle of religion, morality, and even common decency' who 'endeavoured to destroy the confidence of the people in the constituted authorities' and 'fomented insurrections among us'. What made indictments like Morse's especially suggestive was that he drew a systematic connection between the democratic-republican societies, 'the affiliated Jacobin Societies in this country', and what he called the 'astonishing increase of irreligion' ${ }^{81}$ According to historian Rachel Hope Cleves, Morse's sermons inspired many other ministers as well as politicians to focus attention on Illuminati who had only one purpose: "To root out and abolish Christianity, and overturn all civil government. ${ }^{82}$ Reverend Timothy Dwight, President of Yale College, for example, equally building on, and explicitly mentioning, Barruel and Robison, held the French philosophes responsible for breeding atheism. In addition, he held democratic printers in the United States responsible for the dissemination of 'irreligion' and sedition by sending around books and

79 Based on rough calculations, Marcus Daniel thinks that it is plausible that Cobbett sold about 200,000 copies of his own pamphlets between 1794 and 1800, an extraordinary number at the time. The opposition he aroused was so serious that Cobbett was both threatened and prosecuted for seditious libel. Daniel, Scandal \& Civility, pp. 225-230.

8o Daniel, Scandal \& Civility, p. 199; Cotlar, Tom Paine's America, pp. 97-101.

81 J. Morse, A Sermon, Delivered at the New North Church in Boston..., May gth, 1798 (Boston, MA: S. Hall, 1798), pp. 12-24. He delivered a similar sermon to an audience in Charlestown.

82 Cleves, The Reign of Terror in America, p. 91. Morse, A Sermon, p. 21. 
cheap writings. Dwight furthermore elaborated in detail on the massacres in Lyon and Nantes (even mentioning notorious Montagnard radicals such as Collot d'Herbois and Carrier). To prevent such scenes from happening in the United States, Dwight called for the 'harmonious and cheerful co-operation of the citizens'. ${ }^{83}$ Federalist voices such as Dwight's, thus, articulated a particular vision of American citizenship: law-abiding, and obedient to God and (Federalist) government.

These systematic attacks on democrats and the Jeffersonian opposition were combined with the relentless efforts to associate the activities of democratic-republican societies with a supposedly international Jacobin conspiracy responsible for the Terror at a time when the American Republic was caught up in a war with France. They helped to create a climate in which it was almost impossible for Republicans to publicly endorse a transatlantic position and defend the universalistic ideals that were once thought to be shared by Americans and French citizens alike. The Federalist rejection of transatlantic cosmopolitan notions of citizenship already implied an extensive nationalization in comparison to the universalism of 1789-1791. As an 'Enemy to Traitors' wrote in the Federalist Gazette of the United States: 'I am a citizen of the world, said a philosopher. Very well, - so am I. But I am not so much a citizen of the world as to forget that I am a citizen of the United States [...] When we carry our universal citizenship so far as to throw ourselves on the mercy of the world, we shall smart for it' ${ }^{\prime} 4$

To an important extent, this citizenship discourse was shaped by describing what American citizenship was not. Contemplating the meaning of the 'American cockade', a symbol appropriated by Federalists in the 1790 s as counter symbol to the French cockades often worn by democratic Republicans to express their sympathy with France, the Federalist newspaper Salem Gazette of September 7,1798 explained:

The American cockade is now generally worn by those, who would not prefer some other name, than that of American. What does a person who assumes a cockade profess and undertake? He professes himself to owe allegiance to the country, whose characteristics he bears. [...] That he is a friend to the constitution. [...] That no foreign governments can swerve

83 T. Dwight, The Duty of Americans, at the Present Crisis, illustrated in a Discourse preached on the Fourth of July, 1798 (New Haven, CO: Gree, 1798). Dwight also wrote the well-known poem Triumph of Infidelity (1788).

84 American Mercury (Hartford, Connecticut), July 12, 1798. Also cited in Cotlar, Tom Paine's America, p. 98. Cotlar cites the Gazette of the United States (Philadelphia, Pennsylvania), July 2,1798 . 
him from the duties of citizenship. That he is peculiarly, exclusively, and habitually, in his thoughts, actions, hopes, fears, an American' .[...] I say, to the world, that I am an American, that I will demean myself as such, that I am no jacobin, no Frenchman. ${ }^{85}$

But as anti-French sentiments ran rampant, the anti-Jacobin rhetoric of the New England clergy took on hysterical overtones. Anti-sedition laws breaded extreme discontent, and democratic Republicans began to search for resources to combat the Federalist accusations. One crucial and often overlooked turning point in the Republican discourse of the late 1790s was that Republicans started to use anti-Jacobin rhetoric against the Federalists; a rhetoric, as historian Marcus Daniel has put it, that 'exploited rather than challenged popular discontent with France and popular disillusionment with the French Revolution': ${ }^{86}$ The Alien and Sedition Acts backlashed against the Federalists as they generated the founding of many more oppositional Republican newspapers throughout the country instead of curbing them. ${ }^{87}$ Reversing the Federalist accusations of Jacobinism proved to be a convenient stick to beat the Federalist dog.

An expanding network of Republican newspapers, as well as Republican politicians in Congress and state legislatures began to describe the Alien and Sedition Acts in terms with which they had been bombarded for years. ${ }^{88} \mathrm{An}$ 'Address of the Minority of the House of Representatives of the State of Vermont, to their constituents', printed in the Albany Register in January 1799, stated that 'when the freedom of the press is restricted by federal law' $[. .$.$] the$ reign of terror agitates our state'.89 A letter to the 'Republicans of New York', published in the Republican New York newspaper Argus on the August 1, maintained that it can no longer be doubted 'that it is the intention of the federalists to introduce into this country, the system of Jacobinism'. The accusations addressed to the Federalists actually strongly resemble the language Federalists had been using since $1794^{-1795}$ to condemn democratic-republican societies. Federalist fanatics, according to the letter in the Argus, were involved in writing slanderous 'anonymous' letters and 'midnight insults and riots', Moreover, 'sanguinary and abominable publications daily issue from the press of Porcupine and other ministerial prints'; and Republican congressmen were being

85 Salem Gazette (Salem, Massachusetts) September 7, 1798. The article was reprinted in Russell's Gazette. Commercial and Political (Boston, Massachusetts), September 17, 1798.

86 Daniel, Scandal \& Civility, p. 255.

87 Pasley, 'The Tyranny of Printers', pp. 153-175.

88 Cf. Daniel, Scandal \& Civility, p. 255; Cleves, The Reign of Terror in America, p. 93.

89 Albany Register (Albany, New York), January 4, 1799. 
'insulted at a late hour of every night', and 'his family and the whole neighbourhood [were] disturbed by indecencies, which would have disgraced the sansculottes of Paris, even in the time of Robespierre'. Exposing members of the national legislature to such scenes signified 'the end to liberty and law' and raised the spectre of being 'governed by a mob'. Significantly, the letter was followed by an excerpt from Cato's Letters (a body of early eighteenth-century essays by the British writers John Trenchard and Thomas Gordon) on the freedom of thought and speech in particular, suggesting that Republicans were the guardians of an (Anglo-Saxon) intellectual tradition of free speech with which so many Americans were familiar. ${ }^{90}$

Republican publicists also began to actively disassociate themselves from the French Revolution. 'The French have done wrong!' exclaimed an article in the same Argus, a newspaper that for years had been among the most enthusiastic democratic-republican supporters of French revolutionary principles:

does it therefore follow that the politics of 'the Federalists' have been right?' Or, that the Republicans, the Democrats, the Patriots, the AntiFederalists, or whatever you please to call them, are a disorganizing Jacobin French faction, under the direction and control of French influence? [...] No! The conduct of the Republicans holds forth a very different language [...] It shows the Republicans to be what they have all along proclaimed themselves, the firm supporters of our constitution and independence, against the unlawful aggressions of any foreign power, and if possible, against all internal intrigues. ${ }^{91}$

The Boston Independent Chronicle also addressed the Federalist efforts to blacken the Republicans, describing them in a framework of reference that escaped no one: 'The rumor of a conspiracy was an essential part of that system of terror and alarm which your party have adopted. ${ }^{92}$ A county meeting of a number of Virginia 'Freeholders' complained that opponents of the Alien and Sedition Laws had been 'stigmatized as the enemies of the United States, and the partizans of France'. They pleaded 'that they will be among the first to resist the invaders of their country' and 'confidently aver that they despise and

9o $\operatorname{Argus}$ (New York, New York), August 1, 1798.

91 Argus (New York, New York), April 19, 1798.

92 The Independent Chronicle and the Universal Advertiser (Boston, Massachusetts), January 14, 1799 . 
hate sedition, riot, and insurrection, and condemn calumnies against individuals or the government. ${ }^{\prime 3}$

Republicans were thus able to appropriate tropes of order and attachment to the constitution, tropes that had belonged to the Federalist's rhetorical toolbox for most of the 179os. Philadelphia democrats in early July 1798 now toasted on 'The Constitution of the United States - may it be protected against unconstitutional laws, the fatal effects of a system of alarm, and the reign of terror. ${ }^{94}$ There was arguably some opportunism at play in appropriating this highly effective rhetorical means, but it was nonetheless an important step away from French and transatlantic radicalism. It meant, moreover, that Republicans could present themselves as moderate, and civil 'friends of order'. The Anglo-American Painite Thomas Cooper, who had become a prominent Republican journalist in the late 179os, during the state elections campaigns of Pennsylvania in 1799 presented the 'Republican party' as 'attached to representative Constitution', 'averse to war', 'careful of people's lives, and frugal of the people's money' ${ }^{55}$ This was a language employed by Republicans decidedly 'more reasonable and less frenetic', in the words of historian Michael Durey, than ever before.

Republicans not only appropriated anti-Jacobin rhetoric, they also turned away from 'French' principles more generally. The writings of the lawyer, former secretary of the Democratic Society of New York, and Democratic publicist Tunis Wortman, can be seen as an expression of this development. ${ }^{96}$ A prominent supporter of Jefferson's bid for the presidential elections in 1800, Wortman wrote a passionate defence of Jefferson against charges of atheism made by his political opponents. ${ }^{97}$ An important element of his strategy consisted of disassociating Jefferson from French philosophy and atheism:

I am not a friend to the empty fripperies, and badinage, and extravagancies of modern philosophy, nor am I an advocate of the excesses and abuses of that revolution which now convulses France, and astonishes the civilized world [...] I love my own government, because I see in it a

93 The Centinel of Freedom (Newark, New Jersey), January 15, 1799.

94 'A Number of Members of Congress', Time Piece, 16 July, 1798. As cited in: Cleves, p. 93.

95 Aurora, 11 September, 1799, as cited in: Durey, Transatlantic Radicals and the Early American Republic, p. 253. Cooper had been responsible in early 1791 for the abridged popular version of Paine's Rights of Man and migrated to the United States in August 1793 together with Joseph Priestly. Durey, Transatlantic Radicals and the Early American Republic, pp. $3^{2-36 .}$

96 On Wortman, see Young, The Democratic Republicans of New York, pp. 394, 520, 523.

97 Buel, Securing the Revolution, pp. 231-233. 
liberal, rational and practicable form, not springing up by accident, like a mushroom in the night, but growing out of the habits, manners and ancient institutions of the people [...] I know not how it happens that French and American liberty have been confounded: they have scarcely a common attribute. The liberty and religion of Washington is not the liberty and religion of Marat and Robespierre, and Anarchalis [sic] Cloots, that flaming 'orator of the human race'. I make these observations, because some [...] have endeavoured to trace a resemblance between French and American liberty. I abjure and renounce and anathematize all affiliation with the bacchanalian liberty of the great republic. [...] I love and admire that sober and rational liberty which exists in America. ${ }^{98}$

Wortman's turn away from 'the great republic' is noteworthy. In May 1796, in an oration delivered at New York's Tammany Society, Wortman had articulated one of the primary expressions of what Seth Cotlar has called 'popular cosmopolitanism' ${ }^{\prime 9}$ Whereas in 1796 Wortman invoked the transatlantic community of political thinkers, including Godwin, Paine and Priestly, and pleaded for the universal sameness and malleability of the human mind, he now put his hopes for the future on the American government and on American liberty. Certainly, the national reorientation of progressive Jeffersonian democrats such as Wortman did not imply a turn away from emancipatory ideals. Wortman's writings on liberty of the press rank among the most impressive of the time. ${ }^{100}$ But at the beginning of the nineteenth century, both Federalists and Jeffersonian Republicans distanced themselves, and the ways in which they imagined American citizenship, from transatlantic radicalism and Painite cosmopolitanism.

After 1800, in the build-up to the presidential election, Republican publicists not only actively distanced themselves from the French Revolution, some also began to strike a more pacifying chord, indeed a tone of national reconciliation. As a letter in one of the leading national Republican newspapers, the Boston Independent Chronicle, put it in late December 180o:

98 Timoleon [Tunis Wortman], A Solemn Address to Christians and Patriots (New York: D. Denniston, 180o), A Solemn Address to Christians and Patriots (New York: D. Denniston, 180o), in: E. Sandoz, (ed.) Political Sermons of the American Founding Era: 1730-1805, 2 vols. (Indianapolis, IN: Liberty Fund, 1998), vol 2., p. 1496.

99 Cotlar, Tom Paine's America, pp. 49-81.

100 R.W.T. Martin, Government by Dissent:Protest, Resistance, and Radical Democratic Thought in the Early American Republic (New York: New York University Press, 2013), pp. 157-167. 
What, and who are Jacobins? And who are Federalists? Are they not members of the same family, and connected by a common interest? Are there not on both sides men of virtues, of piety, and of talents? [...] Why then keep up these mutual recriminations? [...] Then will a spirit of urbanity, philanthrophy [sic], and patriotism succeed that of discord and contention, and brotherly love, accompanied by peace and tranquillity, will again bless our realm. ${ }^{101}$

Accordingly, Republicans could present themselves as the defenders of the legacy of the American Revolution, as the guardians of the constitution and free speech, as reasonable critics of paranoia, conspiracy thinking, and arbitrary arrests, and finally as a neutral party of peace, associated with neither the French nor the British. In this process they nationalized or Americanized their understanding of citizenship. In his inaugural address on March 4, 1801, the newly elected President Thomas Jefferson gave the most famous expression of this nationalized civic discourse. Externally, the United States were 'Kindly separated by nature and a wide ocean from the exterminating havoc of one quarter of the globe'. Internally he called for unity: 'Let us, then, fellow-citizens, unite with one heart and one mind'. Seeking to bury a decade of contestation and partisanship in which Jefferson had taken no small part, he summoned: 'We have called by different names brethren of the same principle. We are all Republicans, we are all Federalists.' ${ }^{102}$

The nationalized civic discourse that was, thus, forged during and in the aftermath of a tumultuous decade was a far cry away from the moments of transatlantic convergence of citizenship ideals of the early 1790s. Many Republicans, especially those active in, or sympathetic to, the democratic-republican societies of $1793^{-1795}$ had endorsed a transatlantic outlook for much longer. Partly because it was an oppositional discourse behind which those who were dissatisfied with Federalist could rally. More deferential and distinctly antiJacobin models of citizenship articulated by Federalists - although they hardly recognized this as such - bore striking similarities to those conceptions of citizenship as propounded by French Thermidorians in 1794-1795. This FederalistThermidorian parallelism was not the result of transfer, but can be explained by the similarity in their framework of reference which was to an important extent shaped by the Terror, and crucially, how and in what kind of political circumstances they thought the Terror had taken place. By the end of the 179os,

\footnotetext{
101 The Independent Chronicle and the Universal Advertiser (Boston, Massachusetts), December 25,1800 .

102 PTJ, vol. 33, pp. 148-152.
} 
Jeffersonian Republicans articulated their vision of citizenship in more distinctively American terms, dissociating themselves from the transatlantic revolutionary citizenship discourse, from civil discord, from Jacobin insurrection, and from French irreligion. Although it lacked a legal definition of national citizenship, the constitution - the American nature of which Republicans now emphasized - was a central element in this model as guarantee against arbitrary persecution and safeguard for the freedom of speech. The next chapter deals with the question how in the Dutch Republic ideas of citizenship were reconsidered in light of the Terror, and shows that the nationalization and moderation of the American citizenship discourse in reaction to the convulsive 1790 s was not a unique phenomenon in the Atlantic world. We will see that in the Dutch Republic, this process had a dynamic, rhythm, and character of its own. 